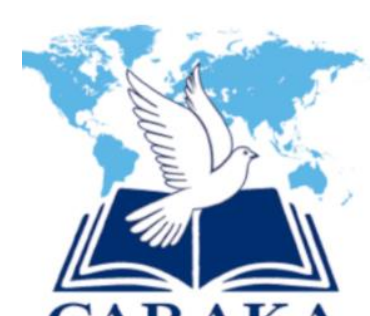

\title{
Signifikansi Kelompok Sel Daring Bagi Jemaat: Sebuah Upaya Pembinaan Warga Gereja Di Masa Pandemi Covid-19
}

\author{
Nanda Kustia Dewa, Lismanwati Laia, Novi Aling Purba, David Eko Setiawan \\ Sekolah Tinggi Teologi Tawangmangu \\ Anandaaji163@gmail.com \\ Lismanwati28@gmail.com \\ novialing9@gmail.com \\ davidekosetiawan14217@gmail.com
}

\begin{abstract}
Indonesia is also one of the countries affected by the Covid-19 pandemic. This disease is troubling the whole community, especially the government, covid-19 is able to paralyze all activities in the community, so the government and health services in Indonesia carry out management for the community, namely by social restrictions, reducing interactions outside the home, and complying with health protocols. So in the midst of a pandemic the use of internet-based technology is increasing, especially worship activities such as cell groups that have been packaged online, this is an effort to foster church members to build intensive communication to review the spiritual growth of the congregation and continue to pay attention to the condition of the congregation in any situation. The method used in this research is descriptive qualitative. The author collects data related to the title of writing by using a library approach. This cell group activity is important because through this fellowship the spirituality of the congregation can be awakened, but due to the Covid-19 pandemic situation, without eliminating all church responsibilities, one of the solutions the author found is to do it online, thus the importance of this online cell group is the congregation. continue to be accompanied, nurtured, guided in the growth of his faith and progress to become a mature believer even in the midst of a crisis situation.
\end{abstract}

Keywords: Online Cell Group; PWG; Covid-19 Pandemic; Significance

\begin{abstract}
Abstrak
Indonesia juga merupakan salah satu negara terdampak pandemi wabah Covid-19. Penyakit ini meresahkan seluruh masyarakat terkhususnya pemerintah, Covid-19 mampu melumpuhkan semua aktivitas di kalangan masyarakat, maka pemerintah serta dinas kesehatan di Indonesia melakukan penatalaksanaan bagi masyarakat, yaitu dengan pembatasan sosial mengurangi interaksi di luar rumah, dan mematuhi protokol kesehatan. Maka ditengah pandemi pemanfaatan teknologi berbasis internet sangat meningkat, terkhususnya kegiatan peribadatan seperti kelompok sel yang sudah dikemas secara daring, hal ini menjadi upaya pembinaan warga gereja membangun komunikasi secara intensif untuk meninjau pertumbuhan spiritual jemaat dan tetap terus memperhatikan keadaan jemaatnya dalam situasi apapun. Metode yang
\end{abstract}


digunakan di dalam penelitian ini adalah kualitatif deskriptif. Penulis mengumpulkan data-data yang berkaitan dengan judul penulisan dengan menggunakan pendekatan kepustakaan. Kegiatan kelompok sel ini penting karena melalui persekutuan ini kerohanian jemaat dapat terbangun namun dikarenakan situasi pandemi Covid-19 ini muncul, tanpa menghilangkan semua tugas tanggung jawab gereja, maka salah satu solusi penulis temukan adalah melaksanakannya melalui daring, dengan demikian pentingnya kelompok sel daring ini jemaat tetap terus didampingi, dibina, dibimbing dalam pertumbuhan imannya serta mengalami kemajuan untuk menjadi orang percaya yang dewasa walaupun ditengah situasi krisis.

Kata Kunci : Kelompok Sel Daring; PWG; Pandemi Covid-19; Signifikansi

\section{PENDAHULUAN}

Menurut WHO (World Health Organization) pandemi adalah penyebaran penyakit keseluruh dunia ( World Health Organization 2020) namun tidak ada definisi yang dapat diterima tentang istilah pandemik secara rinci dan lengkap, beberapa pakar mempertimbangkan definisi berdasarkan penyakit secara umum dikatakan pandemik, dan dengan melihat penyakit serta memeriksa kesamaan dan perbedaannya. Penyakit dipilih secara empiris untuk mencerminkan spektrum etiologi "sebab-akibat" dengan mekanisme penyebaran, dan era kegawatdaruratannya, beberapa penyakit yang pernah menjadi pandemi antara lain: Acute, Hemorr Hagic Conjunstivitis (AHC), Aids, Kolera, Demam Berdarah, Influensa, dan Sars (Morens), (Folkers, and Faudji 2009). ${ }^{1}$

WHO pandemi dikatakan penyakit menyebar keseluruh dunia melampaui batas, ada banyak contoh dalam sejarah dan yang terbaru adalah pandemi covid-19, pandemi yang mirip flu ini dinyatakan WHO pada 12 Maret 2020, wabah ini dikategorikan penyakit menular dan memiliki garis infeksi berkelanjutan, Covid-19 dimulai sebagai epidemi di kota Wuhan, Cina dan selanjutnya menyebar keseluruh dunia dalam hitungan bulan, dan menjadi pandemi. Covid memerlukan penanganan ekstra di negara-negara guna mengurangi menyebarnya virus ini, Di Indonesia sendiri tercatat Sejak 26 Juli 2021, sudah terdapat 3.194.733 kasus, 2.549.692 sembuh, 560.275 kasus aktif dan total kematian $84.766 .^{2}$ Dengan memperhatikan peraturan menteri kesehatan No. 9 Tahun 2020 tentang pedoman pembatasan sosial dalam rangka percepatan penanganan Corona Virus Disiase 2019 (berita negara republik Indonesia Tahun 2020 No. 326). ${ }^{3}$

Kondisi yang terjadi atas Indonesia memicu pihak gereja mempertahankan esensi tugas dan tujuan gereja untuk menjangkau jiwa yaitu memuridkan, agar tidak hilang dikarenakan situasi. Sudah seharusnya gereja mampu mengikuti perubahan zaman, untuk tetap mengambil

\footnotetext{
${ }^{1}$ Rina Tri Handayani et al., "Pandemi covid-19, respon imun tubuh, dan herd immunity," Jurnal Ilmiah Stikes Kendal 10, no. 3 (2020): 37.

${ }^{2} \mathrm{Https} / / /$ covid19.go.id/p/berita/data-vaksinasi-covid-19-update-26-Juli-2021. Pukul 21:00

${ }^{3}$ Menteri Agama RI, "Panduan Penyelenggaraan Kegiatan Ibadah Dan Perayaan Natal Di Masa Pandemi Covid.19" (2020): 4.
} 
bagian dalam melayani secara kreatif, hingga fungsi gereja bukan hanya mempersatukan jemaat tetapi juga ikut terlibat dalam perkembangan pertumbuhan jemaatnya melalui berbagai metode sarana dan prasarana yang dilaksanakan, salah satunya yaitu sistem daring melalui pemanfaatan teknologi berbasis internet seperti Zoom, Google Meet, dan lain sebagainya. Adapun beberapa kajian yang terkait mengenai pemanfaatan teknologi dalam melaksanakan kelompok sel secara virtual di masa pandemi Irwanto berutu dan Evan Siahaan mengatakan kelompok sel mengarah kepada pemuridan yang objeknya adalah jemaat, peneliti ini memaparkan nilai pertumbuhan spiritual jemaat melalui studi literatur dan metode deskriptif yang bertujuan kelompok sel berimplikasi pada pertumbuhan umat karena jemaat terlibat dalam melayani Tuhan. Selanjutnya peneliti Yusuf Rogo Yuono tentang pertumbuhan gereja dimasa pandemi, bagaimana gereja hadir ditengah dunia nyata kehidupan masyarakat dengan segala permasalahannya yaitu covid-19. Maka gereja tetap terus menjalankan tugas untuk melayani jemaat yaitu smart church dengan peralihan dari konvensional kepada digitalisasi, mengenai pertumbuhan jemaat gereja tetap terus diperhatikan apapun situasi zaman yang terjadi. Penulis memiliki kesamaan dengan peneliti sebelumnya, mengenai gereja harus tetap memperhatikan keadaan jemaat dalam perubahan situasi seperti covid-19 dan memanfaatkan perkembangan teknologi, penulis lebih menekankan signifikansi kelompok sel ini dilaksanakan melalui daring. Maka hal tersebut mendorong peneliti untuk mencari sumbersumber data yang berkaitan dengan upaya pembinaan warga gereja melalui kelompok sel daring dimasa pandemi covid-19. ${ }^{4}$ Penelitian ini bertujuan menggali signifikansi kelompok sel melalui daring sebagai upaya mempermudah Gereja untuk membangun komunikasi dan terlibat secara intensif dalam pertumbuhan kerohanian jemaat.

\section{METODE PENELITIAN}

Metode yang digunakan didalam penelitian ini adalah kualitatif deskriptif. Harapan penelitian melalui metode ini adalah dapat meninjau suatu fungsi dari objek tertentu secara detail. Penulis mengumpulkan data-data yang ada dengan menggunakan pendekatan kepustakaan. ${ }^{5}$ Yang bentuknya merupakan suatu proses penemuan dan pengumpulan data, analisis dan interpretasi, baik secara visual dan naratif yang komprehensif untuk mendapatkan pemahaman mengenai suatu yang terjadi yang relevan saat ini, mengenai apa yang didapatkan karena dampak pandemi covid-19. lingkup penelitian ini adalah upaya pembinaan warga gereja yang menerapkan kelompok sel yang kaitannya dengan tujuan penilitian ini,

\footnotetext{
${ }^{4}$ Yusuf Progo Yuono, "Pertumbuhan Gereja Di Masa Pandemi," Sekolah Tinggi Theologia Jaffray 65, no. 2 (2020): 229.

${ }^{5}$ Bagong Suyanto, Metode Penelitian Sosial: Berbagai Alternatif Pendekatan (Jakarta, 2015),14. 223 | Copyright@ 2021, CARAKA, ISSN 2722-1407 (Cetak), 2722-1393 (Online)
} 
menggunakan library research akan menitikberatkan pada bahan ataupun sumber literatur untuk mendapatkan jawaban atas problem Research. ${ }^{6}$

Penelitian ini menggunakan langkah-langkah meta-tesis, yaitu dengan melakukan identifikasi dan interpretasi terhadap hasil penelitian yang berguna untuk menjawab pertanyaan yang timbul dari penelitian dengan topik serta fenomena tertentu, yang sedang menjadi perhatian dan kemudian selanjutnya menghasilkan suatu kesimpulan. Dengan mengangkat kesimpulan yang ada maka metode meta-tesis ini dapat menggabungkan data-data primer yang sejenisnya untuk mendapatkan pemahaman atas seberapa efektif pembinaan jemaat melalui komsel daring., yaitu upaya pembinaan warga gereja saat ini melalui pelayanan kelompok sel daring bagi gereja masa kini di masa pandemi covid-19.

\section{HASIL DAN PEMBAHASAN}

\section{Pentingnya PWG dengan menggunakan Kelompok Sel Daring}

Setiap gereja melakukan proses pembinaan warga gereja pastinya dengan tujuan adanya multiplikasi rohani yang diharapkan, hal ini dapat terwujud ketika kelompok sel pemahaman Alkitab yang berkembang dengan baik. Lewat kegiatan pemahaman alkitab dan persekutuan yang dikerjakan, pastinya seorang pembina kelompok sel dapat menjelaskan pokok-pokok pengajaran kepada setiap anggota jemaat yang tergabung didalam kelompok sel. Lewat interaksi yang dibangun secara berkesinambungan oleh pembina dan anggota kelompok sel, maka kegiatan pengajaran pemahaman alkitab dapat mencapai sasaran yang optimal. Robert E. Coleman mengatakan bahwa metode apapun yang hendak kita pakai, Yesus mengajarkan kepada kita bahwa sangat penting bagi gereja melatih dan melahirkan pemimpin kedepan yang mengerti kebenaran Firman Tuhan dan dapat membangun jemaat, kelompok sel tidak menjadi satu-satunya metode yang paling efektif dalam gereja, namun dimasa pandemi ini kelompok sel yang terkhususnya dikerjakan secara daring sangat penting untuk dikerjakan sebab pembinaan warga gereja memiliki tanggung jawab untuk memperhatikan dan membangun iman serta relasi yang baik. $^{7}$

\section{Definisi dan Fungsi Kelompok Sel}

Wagner menggambarkan bahwa kelompok sel merupakan kumpulan delapan atau dua belas orang percaya yang berkumpul untuk melayani satu sama lain, untuk tumbuh didalam rasa cinta dan persatuan mereka, dan untuk mendorong satu sama lain dengan tujuan untuk

${ }^{6}$ Kartono Kartini, Pengantar Metodologi Research Sosial (Bandung: Alumni Bandung, 1980),78.

${ }^{7}$ Robert E. Colleman, Rencana Agung Penginjilan (Bandung: Yayasan Kalam Hidup, 2016), 87. 224 | Copyright@ 2021, CARAKA, ISSN 2722-1407 (Cetak), 2722-1393 (Online) 
berkomitmen penuh untuk Kristus. ${ }^{8}$ Penulis memiliki gagasan mengenai kelompok sel ini bahwa kelompok sel merupakan sesuatu yang sangat penting untuk digagas gereja, karena melalui persekutuan kecil dalamnya setiap orang mampu berinteraksi lebih intensif secara langsung, yang kemudian bersekutu dengan tujuan bertumbuh bersama dan bermultiplikasi.

Pelayanan melalui kelompok sel beberapa gereja berpendapat sangat efektif dalam merangsang pertumbuhan dan perkembangan gereja. Sukamto dalam bukunya yang berjudul Rahasia Keberhasilan Gereja di Korea secara rinci, menjelaskan perkembangan gereja Yoido Full Gospel yang merupakan gereja terbesar di Korea Selatan ialah karena hasil dari pergerakan kelompok Sel. ${ }^{9}$ Melalui kelompok sel dapat memonitor perkembangan setiap anggotanya. Daniel Sutoyo mengatakan, kelompok sel sebagai wadah pembelajaran gaya hidup Kristen. ${ }^{10}$ Salah satu gerakan rohani yang dilakukan dalam membangun pertumbuhan gereja, yaitu menjadi suatu pergerakan rohani yang melanda seluruh gereja di dunia sebagai sarana penghubung pemimpin gereja dengan jemaatnya, dan sebuah pelayanan yang sangat penting dalam strategi pertumbuhan gereja. Serta kelompok sel sangat berperan penting dalam meningkatkan pertumbuhan kerohanian jemaat yang mencangkup pembinaaan warga gereja, dalam kelompok sel membimbing setiap jemaat terlibat aktif dalam setiap kegiatan jemaat untuk bertumbuh dewasa secara Rohani, karakteristik sebuah gereja mula-mula yaitu tekun dalam bersekutu. ${ }^{11}$

Stockstill secara eksplitis menjelaskan mengenai pentingnya kelompok sel, merupakan jaringan satu dengan lainnya sehingga potensi untuk perkembangan pelayanan dapat bertumbuh secara pesat, bermultiplikasi dengan cara menerapkan prinsip hidup untuk saling mengasihi satu dengan lainnya. ${ }^{12}$ Melalui pola pelayanan kelompok sel, semua orang didalamnya dapat membangun relasi dan saling berkomunikasi dengan lebih nyaman, hal ini juga diungkapkan oleh Berutu dan Siahaan bahwa kelompok sel sejatinya merupakan wadah persekutuan jemaat dalam jumlah yang kecil, menjadi perkumpulan dalam jumlah kecil agar kemampuan berinteraksi satu dengan yang lain lebih baik, dan juga merupakan hubungan antar sesama dengan terjalin lebih kuat dan erat seperti anggota tubuh. ${ }^{13}$

\footnotetext{
${ }^{8}$ Peter Wagner, Your Church Can Grow (Venture: Regal Books, 1984), 124.

${ }^{9}$ Sukamto, Rahasia Keberhasilan Gereja (Yogyakarta: Andi, 2006), 124.

${ }^{10}$ Daniel Sutoyo, "Komunitas Kecil Sebagai Tempat Pembelajaran Gaya Hidup Kristen," ANTUSIAS: Jurnal Teologi dan Pelayanan 22 (2012): 1.

${ }^{11}$ Harls Evan Siahaan, "Karakteristik Pentakostalisme Menurut Kisah Para Rasul," DUNAMIS (Jurnal Teologi dan Pendidikan Kristiani) (2017): 12.

${ }^{12}$ Larry Stockstill, Gereja Sel (Jakarta: Metanoia, 2000), 3.

${ }^{13}$ Irwanto Berutu dan Harls E.R. Siahaan, “"'Menerapkan Kelompok Sel Virtual Di Masa Pandemi Covid-19," Sotiria: Jurnal Teologi dan Pelayanan Kristen 3. N0 1 (2020): 59.
} 


\section{Hambatan Kelompok Sel Akibat Covid-19}

Hambatannya yaitu pembatasan kegiatan untuk bertatap muka, dikarenakan virus corona yang sangat mengancam keberadaan nyawa manusia. Maka untuk mencegah penyebaran corona virus tersebut, mentri kesehatan Terawan Agus Putrantopun memutuskan membatasi kegiatan salah satunya keagamaan, yang dimulai dalam peraturan mentri kesehatan Nomor 18 Tahun 2021 tentang perubahan atas peraturan mentri kesahatan nomor 10 Tahun 2021 tentang pelaksanaan vaksinasi rangka penanggulangan pandemik corona virus disease 2019 (Covid-19) dalam rangka percepatan penanganan Covid-19. Pemerintah juga melaksanakan Pemberlakuan Pembatasan Kegiatan Masyarakat (PPKM) Darurat 3-20 juli 2021 yang diberlakukan dibeberapa provinsi di Indonesia, pada siaran pers di Istana, 2 juli 2021. Dalam rangka percepatan penanganan Covid-19. Dan selanjutnya pembatasan kegiatan keagamaan yang dilakukan di rumah dan dihadiri dengan keluarga terbatas. ${ }^{14}$

Sampai dengan 26 Juli 2021, pemerintah kembali memperbarui data perkembangan Covid-19 di Indonesia. Pertanggal 26 juli 2021 berdasarkan dengan seluruh hasil pemeriksaan total terkonfirmasi virus Covid-19 di Indonesia hingga saat ini mencapai 3.194.733, sembuh 2.549.692, kasus aktif 560.275, meninggal 84.766. salah satu penghambat ini adalah pembatasan ruang gerak manusia untuk berinteraksi dan stay at home. Sementara kelompok sel yang semulanya akan berjalan efektif jika di laksanakan secara langsung atau bertatap muka. Perkumpulan ini menjadi jembatan keakraban atau kebersamaan yang membangun relasi antar jemaat ke jemaat dan gembala juga. ${ }^{15}$

\section{Hambatan Khusus}

Hambatan bukan hanya di luar saja namun adapun kendala dari masing-masing personal, yaitu lokasi jemaat tidak terjangkau jaringan internet, termasuk kuota internet jemaat minim, teknologi atau media yang digunakan masih terbatas dikarenakan tidak semua jemaat paham mengaplikasikannya, keterbatasan alat media, dan terakhir respon jemaat dalam mengikuti daring masih terasa kaku dan seperti satu arah saja, jemaat yang tidak berperan aktif dalam pelaksanaan, jemaat bahkan mungkin tidak mengerti apa yang diterima dalam pelaksaan daring dikarenakan sudah terbiasa mendengar langsung, sehingga jemaat tidak fokus dalam mengikuti daring, yang menyebabkan tidak sedikit jemaat yang tidak berpartisipasi dalam keterlibatan jadwal pelaksanaan daring. Hambatan khusus ini berdampak

\footnotetext{
${ }^{14} \mathrm{Https}$ ://covid19.go.id/p/berita/data-vaksinasi-covid-19-update-26-juli-2021. Di akses 26 Juli 2021. Pukul 19:00 Wib.

${ }^{15}$ Fransiskus Irwan Widjaja, "Menstimulasi Praktik Gereja Rumah di Tengah Pandemic Covid-19," Kurios: Teologi dan Pendidikan Agama Kristen Vol 6, No1 (2020): 135.
} 
besar bagi pertumbuhan spiritual jemaat yang stagnan juga gereja pun mengalami hambat dalam melayani jemaat di masa pandemi covid-19. ${ }^{16}$

\section{Pemanfaatan Tekonologi Berbasis Internet (Daring)}

Perkembangan teknologi yang sangat pesat telah memunculkan perangkat aplikasi yang berbasis internet. Kemajuan teknologi dan komunikasi sangat berperan besar dalam perkembangannya dan tentunya peran digital ini juga berdampak bagi instansi keagamaan yaitu, gereja untuk memberitakan kabar keselamatan, pengajaran akan kekristenan, penginjilan, hal-hal yang berkaitan dengan tugas tanggung jawab gereja. Yaitu, menjangkau jiwa melalui media internet, melalui pemanfaatan internet ini. Kegiatan di dalam gereja pun dapat melalui beberapa aplikasi seperti salah satunya kelompok sel daring ini.

Salah satu riset yang mendukung pelaksanaan kelompok sel ini yaitu melaksanakan daring platform aplikasi zoom, google meet untuk menghubungkan satu akan yang lain dengan jumlah banyak dalam suatu perkumpulan, maka melalui daring inilah kelompok sel akan dilaksanakan menggunakan beberapa aplikasi yang sudah dimiliki jemaat. Melalui daring, hal ini sangat membantu kegiatan kelompok sel untuk tetap terus berjalan, walaupun kemungkinan besar akan ada hambatannya baik dari luar dan dalam, namun tidak menghilangkan tugas gereja dalam menjangkau jemaatnya saat masa pandemi.

\section{Kegiatan dalam Kelompok Sel daring}

Menurut Nee tugas seorang gembala terdiri dari 3 bagian yaitu memimpin ibadah dan menjalankan sakramen, dan mengajar jemaat tentang iman, dikerjakan dengan mengunjungi jemaat artinya seorang gembala memiliki tanggungjawab terhadap kebutuhan spiritual jemaat, dengan memastikan jemaatnya mendapatkan pengajaran yang sehat sebagai kebutuhan rohaninya untuk bertumbuh. Seorang gembala berkewajiban untuk memantau jemaatnya mencapai kedewasaan iman ${ }^{17}$. , jadi pada masa Pandemi ini dapat difasilitasi dengan strategi pembentukan kelompok Sel, dengan mengggunakan platform atau media berbasis intrnet seperti Zoom, Google Meet, Whatssap, dan platform lainnya Sehingga jemaat dapat berinteraksi dengan gembalanya dengan melakukan berbagai kegiatan dalam kelompok sel yang meliputi diskusi tentang kebenaran alkitab, berbagi pengalaman atau kisah hidupnya melalui kesaksian, dan mendukung dalam doa bahkan memberikan pendapat, pandangan,

\footnotetext{
${ }^{16}$ Susanto Dwi Raharjo, "Konstruksi Teologis Gereja Digital : Sebuah Refleksi Biblis Ibadah Online di Masa Pandemi Covid-19," Epigraphe: Jurnal Teologi dan Pelayanan Kristiani 4 (2020): 13.

${ }^{17}$ Watchman Nee, Pekerja Kristus (Bandung: Yayasan Kalam Hidup, 2000), 27-28.
} 
nasehat dalam pemantauan dari gembala atas pertumbuhan kualitas iman, maupun kuantitas jumlah jemaatnya. ${ }^{18}$

Adapun kegiatan yang dilakukan dalam kelompok sel secara langsung sebelum terjadinya pandemi Covid-19, yaitu pemimpin kelompok sel memimpin jemaat dalam pujian dan penyembahan, pujian yang merasakan kesatuan tubuh Kristus dan penyembahan yang mengantarkan jemaat untuk membangun komunikasi dengan Tuhan dan merupakan tahap yang baik sebelum jemaat mendengarkan pengajaran dan firman yang didiskusikan dalam kelompok sel. Pemimpin membagikan Firman Tuhan kepada jemaat untuk menghimbau jemaat dalam mengerti serta menerapkan Firman Tuhan dalam kehidupan di lingkungan gereja ataupun masyarakat, sebab dengan pendalam Firman Tuhan diharapkan seluruh jemaat dalam kelompok sel terlibat aktif untuk penyampaian Injil. Dan adanya sharing antara jemaat pemimpin kelompok sel yang bertujuan untuk saling menguatkan antar sesama, agar terjalin hubungan yang baik dan saling mengenal serta saling membagi kasih. Dan bukan hanya itu saja tetapi juga jemaat dalam kelompok sel dapat saling berbagi tentang firman Tuhan, dapat berupa bahan khotbah yang telah diterima saat beribadah hari minggu atau yang telah direnungkan. Adapun kegiatan lain yang dilaksanakan dalam kelompok sel yaitu ramah tamah atau makan bersama kegiatan tidak diwajibkan tetap jika tuan rumah mampu menyediakannya.

Namun di masa pandemi covid-19 tentunya kegiatan yang dilaksanakan dalam kelompok sel berbeda, karena jemaat harus mengikuti himbauan pemerintah mengenai tata aturan PPKM maka mau tidak mau kegiatan kelompok sel tidak dapat dilaksanakan dengan tatap muka. guna menghindari ketimpangan akan pelaksanaan daring ini, dengan kelompok sel daring tidak berjalan dengan lancar dikarenakan beberapa faktor lain yaitu mempertimbangkan adanya keterbatasan dalam jemaat mengenai alat media seperti handphone, internet, jauh dari jangkauan internet, ekonomi, maka pihak gereja juga membagikan warta jemaat yang berisi informasi dalam seminggu kedepan dan penyampaian kotbah sebelumnya yang akan dibahas kembali dalam pertemuan daring.

\section{Signifikansi Gereja membangun Kelompok Sel Daring}

Persoalan tidak ujung selesai dengan adanya pandemi covid-19, ada berbagai aturan dan kaidah yang mengatur dalam segala bidang terkhususnya pada pembahasan ini adalah kegiatan ibadah, hal ini yang melatar belakangi betapa sangat pentingnya kegiatan gereja yaitu Kelompok sel yang diadakan secara online karena haruslah menyesuaikan keadaan yang terjadi saat ini, maka gereja sangatlah perlu gagasan komsel virtual di masa pandemic covid19, dengan keadaan yang sudah berada saat ini tentunya kelompok sel online atau daring

${ }^{18}$ Irwanto Berutu dan Harls E.R. Siahaan, 53. 
menjadi sebuah alternatif bagi gereja-gereja untuk tetap mengadakan pertemuan, gereja sangat perlu bergerak di arah digital yang berguna untuk menjangkau jemaat di masa pandemi covid-19.

Melihat kebutuhan kelompok sel virtual merupakan langkah yang sangat penting untuk gereja kerjakan di masa pandemi Covid-19, dengan menerapkan kelompok sel virtual kepedulian menjadi sesuatu yang sangat penting karena sebuah interaksi secara langsung membuat anggota kelompok sel bisa Merasakan interaksi itu sendiri, Larry Stockstil mengatakan bahwa pentingnya kelompok sel untuk membangun hubungan yang tidak akan terputus, namun terus membangun jaringan satu dengan anggota jemaat lainnya ${ }^{19}$, yang kemudian berkembang pesat serta menerpakan prinsip hidup saling mengashi satu dengan yang lainnya didalamnya.Terkait dengan pernyataan tersebut maka faktor yang menunjukkan kedewasaan rohani dalam jemaat adalah hubungan antar pribadi. ${ }^{20}$

Di masa Pandemi covid-19 ini, kegiatan ibadah dibatasi dengan berlakunya protokol kesehatan, yang membuat gagasan kelompok sel daring atau virtual ini sangat berdampak bagi kegiatan gereja yang harus dilakukan untuk tetap menjalankan ibadah yaitu dengan penggunaan teknologi mengerjakan kelompok sel dalam wadah pertemuan virtual sudah sangat membantu dalam mengembangkan pertemuan tatap muka dengan jumlah lebih dari dua orang bahkan lebih. Artinya, teknologi tersebut dapat digunakan untuk melaksanakan kelompok sel di masa kini dengan menerapkan physical distancing. ${ }^{21}$

\section{Upaya Pembinaan Warga Gereja Melalui Kelompok Sel Daring}

Dalam upaya pembinaan warga gereja tergabung dalam komunitas kecil maupun dalam komunitas yang besar didalam suatu gereja lokal, sebab komunitas merupakan sarana yang penting untuk mendapatkan informasi,serta mengingat bahwa manusia merupakan makhluk sosial serta membutuhkan komunikasi, Hermawan mengatakan dalam berkomunitas sekelompok orang atau perorangan saling peduli satu dengan lainnya, yang pada akhirnya terjalin komunikasi yang sangat erat berdasarkan kepentingan dan nilai-nilai. ${ }^{22}$

Hal ini sangat berkaitan bahwa kelompok sel daring merupakan upaya gereja melalui pelayanan komunitas. Namun juga terdapat perbedaan yang mencolok dan pelaksanaannya. kelompok sel yang notabennya kumpulan warga jemaat yang berkumpul dengan fokus kepada hal-hal yang bersifat rohani, dan disela-sela kegiatan yang dikerjakan dalam kelompok sel,

\footnotetext{
${ }^{19}$ Larry Stockstill, Gereja Sel.

${ }^{20}$ Ruth F.Selan, Pedoman Pembinaan Waga Jemaat (Bandung: Yayasan Kalam Hidup, 1994), 12.

${ }^{21}$ Irwanto Berutu dan Harls E.R. Siahaan, 53.

${ }^{22}$ Mayang R.N. Fauziyah, N.A. Damayani, and A.S. Rohman, "Perilaku Knowledge Sharing Multi
} Bahasa Pada Komunitas Fakta Bahasa,” Jurnal Kajian Informasi dan Perpustakaan 2, no. 2 (December 2014 ): 91. 229 | Copyright@ 2021, CARAKA, ISSN 2722-1407 (Cetak), 2722-1393 (Online) 
diisi dengan berita firman yang dibungkus dengan situasi komunitas, baik pria, wanita, dewasa, anak muda, dan semua kelompok usia perlu untuk membangun serta memiliki komunitas, sebab setiap jemaat gereja lokal cenderung merasa lebih nyaman di dalam komunitas dibandingkan dalam organisasi gereja, hal tersebut disampaikan oleh Febriati bahwa komunitas membuat orang merasa lebih nyaman dengan suasana yang tidak terlalu formal. $^{23}$

Oleh karena pembinaan warga Gereja di komunitas sangat penting, apalagi di masa pandemi covid-19 perlulah jemaat Tuhan lebih intens diperhatikan, yaitu dengan menerapkan kelompok sel daring. Sebagai pelayan Tuhan yang bertanggung jawab di gereja perlu menunjukkan sikap sebagai pembina warga gereja yang berkaitan dengan fungsi pelayanan pastoral, sebab melalui pendampingan pastoral yang didasarkan dengan tanggung jawab dan lebih serius membuat seseorang yang tergabung dalam kelompok sel daring itu merasa lebih nyaman. ${ }^{24}$

Saat ini kelompok sel hanya bisa dikerjakan dengan kelompok sel daring, karena memperhatikan peraturan pemerintah tentang pembatasan berskala besar, Dalam hal ini peran pembinaan warga gereja dalam kelompok sel dapat melakukan dorongan dan penegasan firman Tuhan dan doa-doa kepada seluruh jemaat yang tergabung dalam kelompok sel daring, yang pastinya dengan memanfaatkan perkembangan teknologi melalui platform WhatsApp, Zoom dan Aplikasi lainnya, seperti halnya yang dibagikan oleh Andar bahwa Kecemasan jemaat terhadap suatu kondisi dapat dialihkan dengan fokus pertumbuhan iman yang lebih progresif. $^{25}$

Maka melalui kelompok sel yang sudah dikemas secara daring, hal ini menjadi upaya pembinaan warga gereja untuk meninjau kebutuhan spiritual dalam pertumbuhan jemaat, upaya ini sebagai tolak ukur pemimpin tetap terus memperhatikan keadaan jemaatnya dalam situasi apapun. Karena situasi tidak membuat gereja berhenti melayani, maka kehadiran teknologi digital melalui internet saat ini membawa pengaruh yang signifikan bagi aspek kehidupan manusia dengan melakukan berbagai macam pelayanan di era digital sekarang ini. Haede A Campbell menyebut fenomena ini dengan istilah cyber churchs yang menerangkan bahwa dalam konteks era digital ini perluasan persekutuan ibadah - ibadah digital tidak lagi dibatasi oleh batas teritorial, karena pada dasarnya kehadiran teknologi menghadirkan kebebasan untuk mengembangkan pelayanan yang dibangun serta disajikan bagi masyarakat

\footnotetext{
${ }^{23}$ Robi Panggara and Leonard Sumule, "Pengaruh Pelayanan Pemuda Berbasis Kontekstual Terhadap Pertumbuhan Gereja Kemah Injil Indonesia Di Kota Samarinda,” Jurnal Jaffray 17, no. 1 (April 2019): 99.

${ }^{24}$ Yohana Brek and Toar H. Umbas, "Grief Pastoral Dalam Pandangan Majelis Jemaat GMIST Musafir Kota Manado,” POIMEN: Jurnal Pastoral Konseling 1, 1 (June 2020): 7.

${ }^{25}$ Gunawan Andar, "Peran Pendeta Dalam Mengatasi Kecemasan Jemaat Gereja Kristen Protestenstan Indonesia Onan Runggu Kecamatan Sipahutar Tapanuli Utara Sumatera Utara,” Chirstian Humaniora 4 (2020): 63.
} 
digital saat ini. Akibat pandemi gereja harus beradaptasi terhadap suatu perubahan, namun tetap mempertimbangkan esensi pendampingan jemaat dimasa sulit seperti ini. Sebagai langkah upaya pembinaan, hal ini menunjukkan kualitas gereja yang hadir dan turut memberikan bantuan bagi seluruh anggota jemaat. ${ }^{26}$

\section{Pelaksanaan Kegiatan Kelompok Sel Daring}

Penulis berpendapat bahwa pembinaan warga gereja dimasa pandemi ini sangatlah penting untuk diperhatikan, oleh karena itu gereja harus menjalankan kelompok sel melalui daring dan dalam keberlangsungannya penulis menemukan tahapan yang dilakukan selama daring, sama hal nya seperti pertemuan kelompok sel pada umumnya diantaranya :

\section{Penyampaian kebenaran firman Tuhan}

Penyampaian firman Tuhan merupakan salah satu bentuk kegiatan didalam konteks kehidupan berjemaat, melalui firman Tuhan yang disampaikan menjadi suatu pembenahan pola hidup yang berkelanjutan untuk terus diperbaharui dalam roh kudus, melalui kelompok sel daring pemimpin kelompok sel dapat menggunakan beragam cara untuk menyampaikan pengajarannya dengan menggunakan media seperti Power point, video, ataupun disampaikan secara langsung. Namun di dalamnya juga perlu diadakan diskusi tentang kebenaran Firman Tuhan yang dipandu oleh seorang pemimpin yang telah dilatih sebelumnya. Dengan demikian anggota gereja akan mengalami pertumbuhan iman yang lebih baik. ${ }^{27}$

\section{Berbagi pengalaman hidup melalui kesaksian}

Tentunya dalam pelaksanakan kelompok sel memiliki tujuan yang sama yaitu untuk bertumbuh bersama melalui berbagai kesaksian yang dilakukan, seperti apa yang telah dijelaskan Kis.2:42-46 sebab yang Allah kehendaki setiap jemaat Tuhan dimanapun berada bertekun dan dengan bersehati berkumpul untuk saling bersaksi didalam bait Allah. Sehingga penulis berpendapat bahwa melalui kesaksian jemaat dapat mengungkapkan bukti pengalaman hidup kepada anggota kelompok sel daring lainnya, jadi melalui kesaksian jemaat akan terus bertumbuh dalam iman. ${ }^{28}$

\section{Diskusi Mengenai kebenaran Firman Tuhan}

Diskusi kebenaran Firman adalah bagian terpenting dalam pertemuan kelompok sel daring, sebab firman Tuhan menjadi tolak ukur pertumbuhan jemaat dalam kedalaman

\footnotetext{
26 Yuono, 229.

${ }^{27}$ Bernard Lubis, "Pengaruh Kelompok Sel Terhadap Pertumbuhan Jemaat Di Gereja Perhimpunan Injili Baptis Indonesia,” Jurnal Pionir LPPM Universitas Asahan 5, no. 3 (2019): 1689.

${ }^{28}$ Amos Hosea, "Fenomena Kelompok Sel (Cell Group) Dalam Gereja Lokal," Diegesis: Jurnal Teologi 3, no. 2 (2019): 1.
}

231 | Copyright $@$ 2021, CARAKA, ISSN 2722-1407 (Cetak), 2722-1393 (Online) 
pengetahuan mereka terhadap firman Tuhan, didalam diskusi ini pendamping kelompok sel berperan untuk berbagi kebenaran firman Tuhan, diharapkan melalui diskusi kebenaran firman Tuhan setiap jemaat yang tergabung dalam kelompok sel daring terlibat aktif merespon kebenaran fiman Tuhan itu, serta menerapkan dalam kehidupannya sehari-hari. ${ }^{29}$

\section{Pujian dan Penyembahan}

Pujian penyembahan merupakan ekspresi terhadap Allah dan merupakan sikap hati yang benar dan respon terhadap Allah, melalui pujian dan penyembahan setiap jemaat yang tergabung didalam kelompok sel menyadari kebaikan Tuhan serta menunjukkan ucapakan syukurnya kepada Tuhan. Tentunya untuk melibatkan setiap anggota untuk memuji dan menyembah Tuhan, pemimpin kelompok sel daring perlu mengajak setiap anggotanya untuk menyembah Tuhan dengan menjelaskan mengenai esensi pujian dan penyembahan itu yang merupakan komunikasi transendental antara manusia dan Tuhan, yang kemudian dilaksanakan sebagai wujud atas respon dari setiap kebaikan Tuhan yang telah dikerjakan bagi setiap jemaatnya. ${ }^{30}$

\section{Keterlibatan Jemaat dalam Pelaksanaan Kelompok Sel Daring}

Keterlibatan jemaat didalam kelompok sel daring tentunya sangat penting bagi berjalannya kelompok sel yang dikerjakan, dengan tujuan memberi peluang jemaat beradaptasi serta ikut ambil bagian dalam pelayan yang dikerjakan, tentunya dengan perubahan pelaksanaan kelompok sel yang saat ini dikerjakan secara daring, maka pembina kelompok sel harus memacu jemaat untuk terlatih menjadi pemimpin melalui kelompok sel. Hal ini berkaitan dengan perkembangan pertumbuhan jemaat yang ditunjukkan dari setiap keterlibatan anggota kelompok sel yang ikut ambil bagian dalam melayani.

\section{KESIMPULAN}

Kelompok sel menjadi salah satu sarana gereja untuk menjalankan tugas gereja yaitu memuridkan seluruh umat percaya. kelompok sel pada umumnya memang diadakan secara langsung, namun dikarenakan situasi pandemi covid-19 ini muncul, tanpa menghilangkan semua tugas tanggung jawab gereja, maka salah satu solusi yang penulis tawarkan adalah melaksanakannya melalui daring, yang kemudian menjadi upaya pelaksanaan pembinaan warga gereja dimasa pandemi covid-19 saat ini.

${ }^{29}$ Ibid.

${ }^{30}$ Irwanto Berutu dan Harls R Evan Siahaan, 53. 


\section{DAFTAR PUSTAKA}

Andar, Gunawan. "Peran Pendeta Dalam Mengatasi Kecemasan Jemaat Gereja Kristen Protestenstan Indonesia Onan Runggu Kecamatan Sipahutar Tapanuli Utara Sumatera Utara." Chirstian Humaniora 4 (2020): 63-71.

Berutu, Irwanto, dan Harls R Evan Siahaan. "Menerapkan Kelompok Sel Virtual di Masa Pandemi Covid-19." E-Journal.Sttpaulusmedan.Ac.Id 3, no. 1 (2020): 53-65.

Daniel Sutoyo. "“Komunitas Kecil Sebagai Tempat Pembelajaran Gaya Hidup Kristen." ANTUSIAS: Jurnal Teologi dan Pelayanan 22 (2012): 1-26.

Fransiskus Irwan Widjaja. "Menstimulasi Praktik Gereja Rumah di Tengah Pandemic Covid19.” Teologi dan Pendidikan Agama Kristen 6 (2020): 135-136.

Handayani, Rina Tri, Dewi Arradini, Aquartuti Tri Darmayanti, Aris Widiyanto, dan Joko Tri Atmojo. "Pandemi covid-19, respon imun tubuh, dan herd immunity." Jurnal Ilmiah Stikes Kendal 10, no. 3 (2020): 373-380.

Harls Evan Siahaan. "Karakteristik Pentakostalisme Menurut Kisah Para Rasul.” DUNAMIS (Jurnal Teologi dan Pendidikan Kristiani) (2017): 12-28.

Hosea, Amos. "Fenomena Kelompok Sel (Cell Group) Dalam Gereja Lokal." Diegesis: Jurnal Teologi 3, no. 2 (2019): 1-11.

Irwanto Berutu dan Harls E.R. Siahaan. “"Menerapkan Kelompok Sel Virtual Di Masa Pandemi Covid-19." Sotiria: Jurnal Teologi dan Pelayanan Kristiani 3 (2020): 59.

Kartini, KArtono. Pengantar Metodologi Research Sosial. Bandung: Alumni Bandung, 1980. Larry Stockstill. Gereja Sel. Jakarta: Metanoia, 2000.

Lubis, Bernard. "Pengaruh Kelompok Sel Terhadap Pertumbuhan Jemaat Di Gereja Perhimpunan Injili Baptis Indonesia.” urnal Pionir LPPM Universitas Asahan 5, no. 3 (2019): 1689-1699.

Peter Wagner. Your Church Can Grow. Venture: Regal Books, 1984.

RI, Menteri Agama. "Panduan Penyelenggaraan Kegiatan Ibadah Dan Perayaan Natal Di Masa Pandemi Covid.19" (2020): 4-6.

Robert E. Colleman. Rencana Agung Penginjilan. Bandung: Yayasan Kalam Hidup, 2016. Ruth F.Seland. Pedoman Pembinaan Waga Jemaat. Bandung: Yayasan Kalam Hidup, 1994. Sukamto. Rahasia Keberhasilan Gereja. Yogyakarta: Andi, 2006.

Susanto Dwi Raharjo. "Konstruksi Teologis Gereja Digital : Sebuah Refleksi Biblis Ibadah Online di Masa Pandemi Covid-19." Epigraphe: Jurnal Teologi dan Pelayanan Kristiani 4 (2020): 13-16.

Suyanto, Bagong. Metode Penelitian Sosial: Berbagai Alternatif Pendekatan. Jakarta, 2015. Watchman Nee. Pekerja Kristus. Bandung: Yayasan Kalam Hidup, 2000.

Yusuf Progo Yuono. "Pertumbuhan Gereja Di Masa Pandemi." Sekolah Tinggi Theologia Jaffray 65, no. 2 (2020): 229-233. 